\title{
Chapter 3 \\ Educational Inequality and Urban Development: Education as a Field for Urban Planning, Architecture and Urban Design
}

\author{
Anna Juliane Heinrich and Angela Million
}

\section{Education in Sustainable Urban Development}

Experts of urban and regional planning increasingly tie questions of sustainable urban development in the transition from a service to an information society to the topic of education as a key economic and location factor in cities and regions. This is especially true in the social urban development of deprived neighborhoods, where actors discuss education (schooling/training opportunities and infrastructures) as a path to integration and societal participation, but also as a means of countering sociospatial disparities and growing polarization. Knowledge and skills acquisition, as well as lifelong learning, raise questions about a suitable neighborhood context and how places of learning are designed, along with specific issues of location development and the design of educational infrastructure and the social urban development of deprivedneighborhoods programs. These programs are created in tandem with urban planners and designers and implemented in communities to ease educational inequality.

Programs and projects based on an expanded understanding of education-in which education takes place not just in schools, but in families, with peers, and in neighborhoods - form the basis of action in German municipalities and at the German federal and state levels, demonstrating that the policy areas and action fields of urban development and education overlap both spatially and in terms of content. A look at the practice reveals shared strands of discussion and analogous and different points of emphasis in supra-local policies and in the municipalities (Heinrich, 2018; Million, Coelen, Heinrich, Loth, \& Somborski, 2017). ${ }^{1}$ Education

\footnotetext{
${ }^{1}$ We have based this whole chapter on the German Research Foundation (DFG) project "Lokale Bildungslandschaften und Stadtentwicklung: Schnittstellen und Verflechtungen" [Local
}

\footnotetext{
A. J. Heinrich $(\bowtie) \cdot$ A. Million

Institute of Urban and Regional Planning (ISR), Technische Universität Berlin,

Berlin, Germany

e-mail: juliane.heinrich@isr.tu-berlin.de; a.million@isr.tu-berlin.de
}

T. Freytag et al. (eds.), Space, Place and Educational Settings, Knowledge and Space 16, https://doi.org/10.1007/978-3-030-78597-0_3 
as an area of policy-making and action will become more significant in the future, particularly in terms of urban development, as seen in the following passage from the German Federal Institute for Research on Building, Urban Affairs, and Spatial Development:

New, key social challenges are emerging right now, including those arising from aspirations of environmental justice, educational justice, social health justice, or inclusion requirements ... Each of these has far-reaching implications and needs for reform, some of which lie outside the municipal area of responsibility, such as, for example, in the field of education. These topics are . . highly relevant to urban development (BBSR, 2015, n.p.; own translation). ${ }^{2}$

At the same time, German actors have almost unanimously answered calls for innovative pedagogical approaches to equal-opportunity education with the development of educational landscapes in recent years, both politically and in educational practice (Bleckmann \& Durdel, 2009; Bollweg \& Otto, 2011). Educational landscapes are currently important projects that bring together diverse development efforts in educational and urban planning in numerous cities and communities. In the following sections we not only discuss sociospatial educational landscapes as a field of intervention and action shared by both the urban development and education sectors, but also the motivations behind them.

\section{Context and Background of Education as Field of Policy and Action in Urban Development and Urban Planning}

Because the terms urban development and urban planning are commonly used in a fairly undifferentiated way, and because we are assuming an interdisciplinary readership, it seems helpful to make a first definition here.

Educational Landscapes and Urban Development: Interfaces and Interlacings], 2014-2017, led by education researcher Prof. Dr. Thomas Coelen, University of Siegen, with Christine Loth and Ivanka Somborski, as well as city planner and urban designer Prof. Dr. Angela Million, Technische Universität Berlin, with Dr. Anna Juliane Heinrich. We focused our research on the content-related and spatial overlap between the fields of education and urban development at the federal, state, and local levels. In this study, we analyzed key department records and interviews with representatives of federal and state ministries, as well as municipal umbrella associations. We also explored the concept of sociospatial educational landscapes. We have based this article on the monograph Gebaute Bildungslandschaften [Built Educational Landscapes] (Million et al., 2017) with contributions by Angela Million, Thomas Coelen, Anna Juliane Heinrich, Christine Loth, and Ivanka Somborski and have supplemented it with results from Anna Juliane Heinrich's doctoral research: Die sozialräumliche Bildungslandschaft Campus Rütli in Berlin-Neukölln [The sociospatial educational landscape Campus Rütli in Berlin-Neukölln].

${ }^{2}$ The quote comes from a preliminary study entitled Neue Themen und Akteure für eine soziale Stadtentwicklung generieren [Generating New Topics and Actors for Social Urban Development] (BBSR, 2015), conducted by the German Federal Institute for Research on Building, Urban Affairs, and Spatial Development (BBSR) to clarify where, or in which thematic areas, stronger cooperation is needed. 


\section{Urban Development and Urban Planning}

Urban planning is understood as "the anticipatory management of the spatial development of a city" (Albers, 2005b, p. 1085; own translation). We speak of the discipline of urban planning since the first decade of the twentieth century. At the time, urban planning was understood as reactive-merely supposed to guide the "development forces of economy and society that appear to be uninfluenceable" (Albers, 2005a, p. 1067; own translation). Until the 1960s, scholars used the term urban development to refer to these development forces (Friedrichs, 2005, p. 1059). Since then, however, the term's understanding and use has shifted. The more recent understanding has increasingly included the notion that tools should be used to intervene in and steer urban development (Albers, 2005a, p. 1067; 2005b, p. 1085). In planning scholarship and practice today - and also in this chapter-the term urban planning is understood as the narrower term which primarily describes the "steering of spatial development" (Albers, 1983, p. 342; own translation), whereby the central subject-matter is the urban structure (Albers, 2005b, p. 1089). Urban development, again, is "the endeavour to act in an integrated manner in social, economic and spatial terms" (Albers, 2005a, p. 1070; own translation) and embraces both the general development of a city and interventions meant to steer and intervene in this development.

In the beginning, experts primarily saw urban planning as the sole responsibility of the public sector (Sinning, 2007, p. 303). This planning self-concept has changed since the mid-1970s - from the rational and technically justified pretense of truth and omniscience on the part of planners (Rittel \& Webber, 1973) to more incrementalism and communicative planning. The still-ongoing shift of planning practice toward a more cooperative and participatory process of urban production (Altrock, 2014; Forester, 1999; Healey, 1997) spurs the development of numerous methods and techniques for participation in planning processes (Altrock, 2014, p. 23; Bischoff, Selle, \& Sinning, 2007, p. 26). Planning theorists described this progressive change as the "communicative turn" (Healey, 1996), closely related to the "argumentative turn" (Fischer \& Forester, 1993). Scholars, at least in the German context, now take for granted that a multitude and diverse array of actors influence and shape a city's development and need to be part of it (Selle, 2012, p. 29). Analytically, actors involved in urban development are divided into three social spheres: the political and administrative state system, the economy, and civil society (Albers, 1983, p. 342; Selle, 2012, pp. 29-30; see also Heinrich, 2018).

In line with this understanding of planning as a communicative process involving divers stakeholders urban planning is concerned with a reconciliation of interests and different demands placed on the city are organized and moderated. This ties in with the desire to take integrative or inclusive action in social, economic, and spatial areas (Albers, 2005a, p. 1070), and to deal with these issues in an extensive, futureand goal-oriented way beyond departmental limits (Sinning, 2007, p. 303). This is a city-shaping process, in which various actors have increasingly heterogeneous interests and claims-to-use regarding space. Further challenges for urban 
development include globalization, demographic change and segregation, new housing requirements, and financial difficulties of the municipalities. An increasingly common refrain is that the scope and complexity of these challenges exceed the municipalities' creative and economic potentials. This is why cooperation between the aforementioned actor groups and an interdisciplinary, integrated approach to urban development is so crucial. Planners of sustainable urban development must take into account these various demands and reconcile them with one another to remain spatially compatible and viable in the future.

\section{Education-Related Urban Development}

Whereas planning practice and scholarship since the 1970s has focused primarily on the quantitative securing of spaces for formal education (schools, in particular) (Libbe, Köhler, \& Beckmann, 2010, p. 43), actors are increasingly practicing and exploring qualitative approaches (e.g., "good schools") primarily, but not only, in connection with deprived neighborhoods. Reasons for the growing importance of education as part of integrated urban development include, but are not limited to, urban development's still-growing focus on physical holdings, burgeoning emphasis on the neighborhood as a key benchmark level, greater orientation towards social space, and the above-mentioned changing understanding of urban development and planning. Further planning considerations include the increased importance of local educational settings in the context of social urban development of deprived neighborhoods (Bundestransferstelle Soziale Stadt, 2006 [German Federal Transfer Office for the "Social City programme"]), the shift towards a knowledge-based society and its influence on planning (Zimmermann, 2010), and the development of so-called knowledge regions or knowledge-based urban and regional development (Matthiesen \& Mahnken, 2009; Mecklenbrauck, 2015).

Municipal planning has sovereignty in Germany, which means that local authorities have the right to regulate and take responsibility for all local affairs within the existing legislative framework. ${ }^{3}$ At the same time, in interplay and coexistence with German federal programs and policies, the German states, but also the municipal associations and numerous foundations, have an influence on education-related urban development.

\footnotetext{
${ }^{3}$ German formal education is organized in a division of tasks between municipalities and states, particularly with regard to schools. Cities and municipalities are "school authorities" and thus responsible for "external school matters." The state bears responsibility for "internal school matters." The "external school matters" to which towns and municipalities must attend include the construction of school buildings and school maintenance (procurement of equipment, materials, support services and the auxiliary staff). "Internal school matters" handled by the state include defining educational goals, setting curricula and hiring teachers. The split between roles is reflected in school funding. Cities and municipalities bear the costs of school operation (construction and operation of the school buildings, learning aids, building staff, special assistance, student transport, etc.), whereas states pay the teachers' salaries.
} 
A formative factor in today's urban development in Germany is the focus on sustainable development - as mentioned above in this chapter's introduction- that emerged in the early 1990s. Proponents of sustainable development consider education as an important topic and field of action for both urban development practice and policy-making. ${ }^{4}$ The authors of the "LEIPZIG CHARTER on Sustainable European Cities" articulate principles and strategies for sustainable urban development policy in the European Union, explicitly naming education as part of sustainable urban development (BMUB, 2007). They present and discuss education as a subject area for sustainable urban development in various forms, arguing that educational infrastructures, but also infrastructures for health and social services, influence quality of life and are economic location factors in cities. Knowledge creation and sharing in cities is to be reinforced, among other things, through high-quality educational institutions, opportunities for lifelong learning, and knowledge transfer structures - among other things through the development of networks and improvements to structures on site (BMUB, 2007, pp. 4-5). The authors of the LEIPZIG CHARTER explicitly name and promote an activating child and youth policy, as well as improvement to the vocational training and education situation, as important strategies for adding value to disadvantaged urban neighborhoods where an aboveaverage proportion of children and adolescents are regularly affected by educational disadvantages and inequalities in education. This requirement undoubtedly reflects the challenges many European states face when dealing with increasing tendencies toward segregation (Häußermann, 2002).

Besides the Social City programme (one of the Federal Government's urban development assistance programs) — which we discuss in the following section - the so-called National Urban Development Policy and its model and pilot project funding scheme are used to support innovative, transferable approaches that put LEIPZIG CHARTER principles into municipal practice and can also be taken up by others. ${ }^{5}$ In this context, several different projects have made direct and indirect reference to the city and the district as an educational space and opportunity (BBSR, 2017a). The leaders of a large number of funded model projects address educational events in the form of good, participatory processes as an important and "creative" boost for urban transformation (BBSR, 2017b). Other model projects implemented since 2008 are

\footnotetext{
${ }^{4}$ Its first aim is to contribute to "intra and intergenerational equal opportunity" (Spehl, 2005, p. 679; own translation). Legislative anchoring of the sustainability principle as a guiding idea for spatial development came in 1998 with an amendment to the Spatial Planning Act (Sinz, 2005, p. 866), whose authors envision "a sustainable spatial development that reconciles social and economic demands on space with its ecological functions and leads to an enduring, large-scale, balanced order with equal living conditions in all sub-areas" ( $\$ 1$ (2) ROG; own translation). These guidelines have been translated, among other things, into municipal sustainability concepts (or urban development concepts focused on sustainable development) that many cities and municipalities in Germany have set up. Education appears as a field of action here and is primarily discussed under the catchphrase "social and integrative city" (Grabow \& Uttke, 2010).

${ }^{5}$ Website for the National Urban Development Policy: http://www.nationale-stadtentwicklungspolitik.de/NSP/EN/Home/home_node.html;jsessionid=EA95B22CD5E87733F0EC35DE 5A1C8777.live11293
} 
clearly centered around developing educational opportunities and educational landscapes in the neighborhood. Representatives from these model projects published a thesis paper as a catalyst for the planning-practice debate (Biernath et al., 2009; Steffen et al., 2009). The authors view the paper as a supplement to the LEIPZIG CHARTER and put forward three theses in "Die Rolle der Bildung in der Nationalen Stadtentwicklungspolitik" [The Role of Education in National Urban Development Policy] (Burgdorff \& Herrmann-Lobreyer, 2010, p. 153):

- First, they determine that "educational facilities and opportunities shape the urban district" (Biernath et al., 2009, p. 2; own translation).

- Second, they warn that "education, and with it, equal opportunities and the integration of parents and children, can also be made more difficult by inappropriate planning measures and urban developments" (Biernath et al., 2009, p. 3; own translation).

- And third, they request that "urban development planning and educational planning must be brought together" (Biernath et al., 2009, p. 3; own translation).

Lastly, a number of international building exhibitions (IBAs) in Germany ${ }^{6}$ have demonstrated the growing importance of education as a topic for planning innovation in dealing with the challenges of urban development. In 2010, the majority of cities in the IBA Urban Redevelopment Saxony-Anhalt conceived education as a strategic component in the enhancement of a city's image, and thus as an aid to coping with processes of urban shrinking (MLVLSA, 2010). The IBA Hamburg integrated issues related to the new, knowledge-society city and the need for novel pedagogical architecture into its considerations on the Future of the Metropolis ${ }^{7}$ (IBA Hamburg, 2009). And the IBA Heidelberg made education the guiding theme of an international building exhibition for the first time, with its motto Knowledge | Based | Urbanism (Stadt Heidelberg, 2012).

\section{Education as a Field of Action in Social Urban Development of Deprived Neighborhoods}

The role of education in the social urban development of deprived neighborhoods came into focus parallel to the increased importance of education in urban development policy (in more detail see: Heinrich, 2018, pp. 41-44). In the 1990s, greater inequality between and within German cities emerged so strongly that there was

\footnotetext{
${ }^{6}$ The international building exhibition or IBA is a presentation and working format in cities and regions for implementing new, standard-setting concepts and solutions with international appeal for today's urban development challenges. A number of projects and initiatives are implemented, in general, for a limited period of time (about 10 years) and usually with support from a targeted combination of various public funds (IBA Hamburg, 2010).

${ }^{7}$ The IBA Hamburg addressed, among other things, the extent to which the spatial concentration of formal and informal educational institutions for children, adolescents and adults held particular potential for new forms of learning in the transition from an industrial to a knowledge-based society (IBA Hamburg, 2009).
} 
talk of a "crisis of cities" by the end of that decade (Häußermann, Läpple, Siebel, 2007, p. 183; own translation). This meant both a crisis of integration in the face of growing inequality as well as a crisis in urban policy, as its actors apparently lacked the tools to support social cohesion (Häußermann \& Siebel, 2004; Stegen, 2006, p. 11). One consequence of the manifold changes was an increase in the sociospatial differentiation of urban districts. Processes of social segregation have taken place, and are taking place, in many German cities in tangible terms, and they continue to be manifested to this day.

However, educationally segregated districts with dropout rates between $10 \%$ and $15 \%$ face more than just the challenge of improving school performance and qualifications for their children and adolescents. They also call for answers to many social issues that are not reflected in the curricula and, accordingly, cannot be solved in the school system alone. Many communities have also seen reinforced cooperation between schools and out-of-school educational institutions, often supported by funds from the Social City programme. Such collaboration can include the organization of transitions between day-care facilities and school, or school and work; the joint training of a district's pedagogical staff on specific issues, such as intercultural competence, violence prevention, or language development; cooperation between school and extracurricular education such as libraries or youth and cultural institutions; and improving cooperation with parents in the neighborhood.

In the 1990s, these developments led to a "political dynamic in the field of social urban policy" (Güntner, 2007, p. 147; own translation). The first programs were initiatives at the municipal level and funding programs initiated by some federal German states (Berlin, Bremen, Hamburg, North Rhine-Westphalia). With some delay, the approaches were adopted across Germany, and in 1999 the program "Social City: Investments at the Neighborhood Level" (at that time called "Districts with Special Development Needs: The Social City," or "Social City" for short) was brought into being (see Güntner, 2007, p. 147; Häußermann \& Siebel, 2004, p. 171). The program's aim was, and still is, "to stabilize and upgrade developmentally, economically and socially disadvantaged and structurally weak urban areas and districts" (BBSR, 2017c; own translation). Häußermann and Siebel (2004, p. 171; own translation) describe the novelty of the program five years after implementation as follows: "The innovative thing about this program is that urban and social problems are viewed in relation to one another, and therefore projects focused on improving the social situation and developing the community should also be funded alongside structural renewal projects." This marks a departure from a primarily buildingfocused urban policy towards a social space-oriented urban development (Häußermann \& Siebel, 2004, p. 171).

School and education as a field of action was initially of only secondary importance in the Social City programme and was reduced to the technical aspect of infrastructure (Böhme \& Franke, 2015, p. 39). However, the third nationwide survey of the Social City programme areas (Bundestransferstelle Soziale Stadt, 2006) revealed an impressive boost in significance. The report's authors wrote that about three-quarters of all integrated urban development concepts discussed "school and education" as a concept (Bundestransferstelle Soziale Stadt, 2006, pp. 10-13). 
Whereas only $17 \%$ of the program areas in 2002 aimed to integrate schools into the neighborhood, this figure rose to $47 \%$ in 2006. Moreover, educational institutions have become "a permanent partner in developing integrated development concepts" (Bundestransferstelle Soziale Stadt, 2006, p. 13). In 2006, some 63\% of the program areas involved educational institutions in working out development concepts, compared with about $45 \%$ in 2002 . A reason for the high importance of "school and education" as a field of action in the Social City programme is that an above-average proportion of children and adolescents in the program areas are regularly affected by educational disadvantages (BMUB, 2014, p. 16).

The 2014 Social City Status Report (reporting period 2009-2014; BMUB, 2014) demonstrates that actors were interpreting and treating the field of "school and education" in a much more varied way than at the beginning of the program: Its declared objective was "to complement formal school education with a variety of informal educational opportunities in the living environment 'outside one's doorstep' and also 'in the city,' or to harmonize the two" (BMUB, 2014, p. 17; own translation). The range of topics and measures covered includes, but is not limited to, cooperation between neighborhood management and educational institutions, networking between educational institutions and other actors in the neighborhood, improving transition management between educational institutions, the opening of schools and further development to neighborhood centers, expansion of the range of services offered by the schools, improvements to the living environment with a focus on learning and games, the creation of recreational activities (e.g., sports and cultural activities), language development and health promotion, parenting skills support, and violence and crime prevention (BMUB, 2014, pp. 16-17; Böhme \& Franke, 2015, pp. 38-40; Million et al., 2017, p. 4).

In 2011, federal-level policymakers took up the growing importance of the "school and education" field of action in the program areas. With the further development of the Social City programme, the "improvement of child, family and elderly and other social infrastructures" (Böhme \& Franke, 2015, p. 40; own translation) has become a substantive focus. Finally, the 2014 Social City Status Report states: "The topic of 'educational landscapes' has gained significant momentum in the Social City programme in recent years" (BMUB, 2014, p. 17; own translation).

\section{Educational Landscapes}

In contrast to educational networks - which can be found in the literature and in practice in Germany - the term educational landscapes is more frequently used in the planning and design professions, but also by architects and planners, as it apparently implies a spatio-physical situation on different levels of scale (for example, building, plot, block, neighborhood, district, entire city, region, as well as public and private spaces) (Million et al., 2017, p. 8). There is no consensus definition of $e d u$ cational landscapes as a new guiding concept (Mack, 2008), even across different disciplines. For instance, Bleckmann and Durdel (2009, p. 12; own translation) 
define educational landscapes as "long-term, professionally designed and local, politically desired networks around the topic of education that - taking the learning subject's perspective as a starting point-are comprised of both formal educational facilities and informal learning worlds and refer to a defined local area."

In 2009, Berse offered a first typification considering the underlying conceptions of space and education, the actors involved, the importance of cooperation between youth welfare services and schools, and the type of control applied. He distinguishes between four types of educational landscapes:

1. Cooperation between youth welfare service and school

2. School and school development design

3. Lifelong learning, further training, economy

4. Social space as educational space

The fourth type is particularly productive with regard to overlaps and interdependencies between education and urban development as topics and fields of action. Researchers use it to refer to educational landscapes that are "characterized by the orientation of education policy networking towards social space as an educational space" and "the design of the socio-spatial living conditions ... as a basis for educational processes" (Berse, 2009, p. 202; own translation). Implementing sociospatial educational landscapes brings a "spatial perspective" to education and the shaping of sociospatial living conditions is considered a basis for educational processes.

\section{Characteristics of Sociospatial Educational Landscapes}

Drawing upon the empirical data of eight case studies on sociospatial educational landscapes, education and planning scholars Million et al. (2017, pp. 205-208) sharpen the broader definitions by reconstructing four constitutive elements of educational landscapes and calling them "sociospatial educational landscapes." They describe the common features of sociospatial educational landscapes in practice:

Diversity of participating institutions: The first constitutive element of sociospatial educational landscapes comprises the broad and diverse spectrum of actors, which is also characteristic of other types of educational landscapes. Partners in sociospatial educational landscapes are frequently organizations from the fields of early childhood education, (all-day) school education, child and youth work, cultural education, adult education, and health care. Cooperation in sociospatial educational landscapes is not limited to education-related topics, but equally includes urban(-spatial) relationships between organizations. A particularly important factor here is the creation of spatial proximity between partner institutions, which, among other things, is meant to intensify cooperation and communicate their connection to the outside world. 
Various forms of organizational cooperation: The second constitutive element of sociospatial educational landscapes is the organizational cooperation between participating institutions. The participants characteristically understand themselves as partners and develop and establish structures that enable long-term cooperation. They usually set up non-formalized networks and use various forms of voluntary participation (e.g., shared mission statement, cooperation agreement), always basing cooperation on joint objectives.

Integration of educational and urban planning aspects in the overall concept: Another common feature is that pedagogical and spatial aspects are linked in the mission statements, goals, concepts, and the implementation of strategies and measures of sociospatial educational landscapes. This becomes particularly clear on the basis of practical cases implemented using the urban development concept of the campus. The campus is intended to create attractive open spaces and make integrated use of infrastructures, on the one hand, while also facilitating school career-related transitions through users' familiarity with the clearly defined space. Sociospatial relations: Sociospatial relations form the fourth constitutive element of sociospatial educational landscapes. Space is a key category in conceiving and implementing sociospatial educational landscapes. This means that the projects are understood not only as actor networks, but also as urban development projects. In particular, the physical materialization of sociospatial educational landscapes includes, for example, the creation of new or existing green and open spaces, the connection of existing buildings with new architectures, as well as spatial networking through additional pathways. A key question here is often to what extent and in what form relationships between the district and educational landscape are designed and how open and public an educational landscape is.

These unique features of sociospatial educational landscapes (particularly in contrast to educational landscapes that function primarily as institutional educational networks) presuppose another characteristic: In action, not only educators but also architects, urban, and landscape planners are co-designers of sociospatial educational landscapes. The actors, with their different motivations, pursue shared goals (presented in the following sections) that are based on a common understanding, especially in respect of deprived neighborhoods. Heinrich (2018, pp. 296-297; own translation) elaborates on the unifying understanding that underpins the actors' engagement in educational landscapes in the social urban development of deprived neighborhoods 8 :

- "mutually-reinforcing problem areas in local education and neighborhood development (esp. the links between segregation and the quality and image of educational institutions);

\footnotetext{
${ }^{8}$ Based on interviews and document analyses, Heinrich (2018) analyses the sociospatial educational landscape Campus Rütli.
} 
- low impact of disciplinary and department-specific approaches to urban planning and pedagogy and the realization that complex problems can only be resolved with integrated, holistic solutions;

- educators and/or urban planners lack the necessary power and access to impact their own area of responsibility, and this can only be done through crossdisciplinary and interdepartmental cooperation;

- similar, in some cases identical, objectives between urban planners and educators;

- the realization that actors at points of overlap (e.g., neighborhood management) create special qualities with their work and have a high innovation potential;

- the expectation that the integrated conception and implementation of [a sociospatial educational landscape] [...] will tap into synergies and thereby increase project effectiveness;

- realization that the integrated use of existing resources (e.g., know-how, funding) can help implement measures and increase project efficiency;

- urban planning methods, procedures and tools promote the structuring of crosscutting issues (e.g., integrated urban development concepts);

- various policies and programs promote integrated action (e.g., the Social City programme, the policy framework to enhance social space orientation)"

In our view it is indeed remarkable that actors from very different disciplines and departments share this understanding. The reference to an earlier empirical study by Duveneck (2016) describing conflicts between actors suggests that a common understanding has, at least partly, grown out of the process of cooperation. However, based on the case studies and with a view to the broad field of practice, Heinrich (2018, p. 248; own translation) asserts that at present "we cannot speak of a matter of course or even "mainstreaming"".

\section{Implementation of Educational Landscapes: Examples}

Germany had an estimated 400 educational landscapes in 2017, of which around two dozen can be classified as sociospatial educational landscapes (Million et al., 2017, p. 9); not all are implemented in deprived neighborhoods. Compared to the number of single school buildings eracted in the same time span educational landscapes are (still) a numerically rather small phenomenon. It is striking that this small number of soci-spatial educational landscapes have gained very high visibility in politics, practice, and research. Although sociospatial educational landscapes are by no means representative of educational landscapes, this type dominates the debate in practice. Sociospatial educational landscapes regularly appear in planning — but also in education-related - professional congresses, events, or publications that examine the practice.

Million et al. (2017) have studied examples of sociospatial educational landscapes intensively. Those that are completed and in operation include Bildungszentrum Tor zur Welt ["Gate to the World" Education Center] (Hamburg), 
Campus Technicus (Bernburg), and the Campus für lebenslanges Lernen [Campus for Lifelong Learning] (Osterholz-Scharmbeck). Sociospatial educational landscapes that are currently being conceived and realized include the Bildungslandschaft Altstadt-Nord [Altstadt-Nord Education Landscape] (Cologne), Campus Rütli (Berlin), and the Quartiersbildungszentrum Morgenland [Morgenland Neighborhood Education Center] (Bremen). ${ }^{9}$ All these examples show that the practical implementation of sociospatial educational landscapes is typically embedded in co-funding structures (federal or state funding together with foundations) (see sections on Education-Related Urban Development and Education as a Field of Action $)^{10}$.

Some projects outside of Germany can also be characterized as sociospatial educational landscapes. Examples include brede scholen in the Netherlands or extended schools in the United Kingdom (see Baumheier \& Warsewa, 2009, p. 24; du BoisReymond, 2011, pp. 519-521; Million, Heinrich, \& Coelen, 2015, pp. 595-596; 2017, p. 9).

In the following sections, we take a closer look at the Campus Rütli in Berlin, which scholars often cite as an educational landscape in the context of social urban development of deprived neighborhoods. Before this, however, we explore another case, the Quartiersbildungszentrum Morgenland [Morgenland Neighborhood Education Center] in Bremen. These two cases show how differently sociospatial educational landscapes in deprived neighborhoods are designed and arranged.

\section{Morgenland Neighborhood Education Center in Bremen-Gröpelingen}

The Morgenland Neighborhood Education Center is the third district education center (QBZ) set up in the city of Bremen to date. Neighborhood education centers accommodate various institutions and provide (further) education and counseling services. Managers of neighborhood education centers are also obliged to support the organizational cooperation of educational institutions in the neighborhood. The neighborhood education center as a building should serve as a place of exchange for the target groups, neighborhood residents, and representatives of the educational institutions. Usually, neighborhood education centers are implemented as new and supplementary buildings at existing elementary schools. Physical proximity to an elementary school is meant to ensure that the neighborhood education center is visited often, and to foster a connection to the local residents via the catchment area.

\footnotetext{
${ }^{9} \mathrm{An}$ in-depth description of this and other sociospatial educational landscapes can be found in Million et al. (2017, pp. 80-203). Heinrich (2018) presents a detailed analysis of Campus Rütli.

${ }^{10}$ Sociospatial educational landscapes are funded in the context of state and federal education ministry programs, as well as by and with foundations, such as the Lernen Vor Ort [Learning On-Site] program (German Federal Ministry of Education and Research, 2009-2014), the Ein Quadratkilometer Bildung [One Square Kilometer of Education] program (One Square Kilometer Foundation, since 2006), the pilot project Selbstständige Schule [Independent School] (State of North Rhine-Westphalia and Bertelsmann Foundation, 2002-2008), or various projects headed by the German Youth Institute (DJI).
} 
Neighborhood education centers are aimed at stabilizing neighborhoods or entire urban districts by enhancing the framework conditions for the growth of children and adolescents through improved educational opportunities and successful transitions between them. Adults are to be provided with counseling and continuing education programs. Neighborhood education centers are conceptually grounded in integrated, cross-departmental, and social space-oriented action. Although policymakers planned several neighborhood education centers for Bremen from the outset, they applied no uniform concept to different locations. Instead, the neighborhood education centers are being developed on a local basis and focused on local potentials from a resource-oriented perspective (Fig. 3.1).

Neighborhood education centers are not (yet) socioeducational landscapes as we conceive them. Rather, we interpret neighborhood education centers as a funding structure for the development of sociospatial educational landscapes. They can also be seen as an instrument for the social urban development of deprived neighborhoods. Compared to the other educational landscapes we are examining here, it is particularly interesting that neighborhood education centers make an entire neighborhood-an entire urban district, in the case of Morgenland Neighborhood Education Center-an educational landscape.

With 35,000 residents, the urban district of Gröpelingen is a structurally disadvantaged area in the Hanseatic city of Bremen. It joined Bremen's WiN (Wohnen in Nachbarschaften/Living in Neighborhoods) program in 1998. Ten years later, the Senator for Education and Social Affairs in Bremen decided to establish three neighborhood education centers in structurally disadvantaged neighborhoods, including Gröpelingen. Initiated by the Lernen vor Ort [On-Site Learning] program, a working group was founded to set up a local educational bureau to address the following questions: "How can long-term educational barriers in Gröpelingen be overcome? How can local educational institutions make their cooperation more coherent? How can educational services be tailored to the needs of children, young people and families in order to overcome educational disadvantages?" (Senatorin für Bildung und Wissenschaft [Senator for Education and Science], 2014, p. 1; own translation).

Policymakers planned the Morgenland Neighborhood Education Center (see Fig. 3.2) in the following years, and in 2014 it opened on-site beside an existing elementary school. Schools, day-nurseries, and urban district institutions work together in the neighborhood education center to improve educational opportunities for the district's children and youth. Actors view it as a new building block for the Gröpelingen education landscape, which complements already existing opportunities. It is home to a workshop for project-related work (MO 34), uses the elementary school cafeteria, which can be used for events in the afternoon, provides office space for the local educational bureau tasked with overall coordination, outreach educational counselling, and includes the office of the WiN (Wohnen in Nachbarschaften/Living in Neighborhoods) program. "QBZ MORGENLAND also offers numerous services to support parents, advise residents and strengthen families" (Kultur Vor Ort e.V., 2017; own translation) (see Fig. 3.2). 


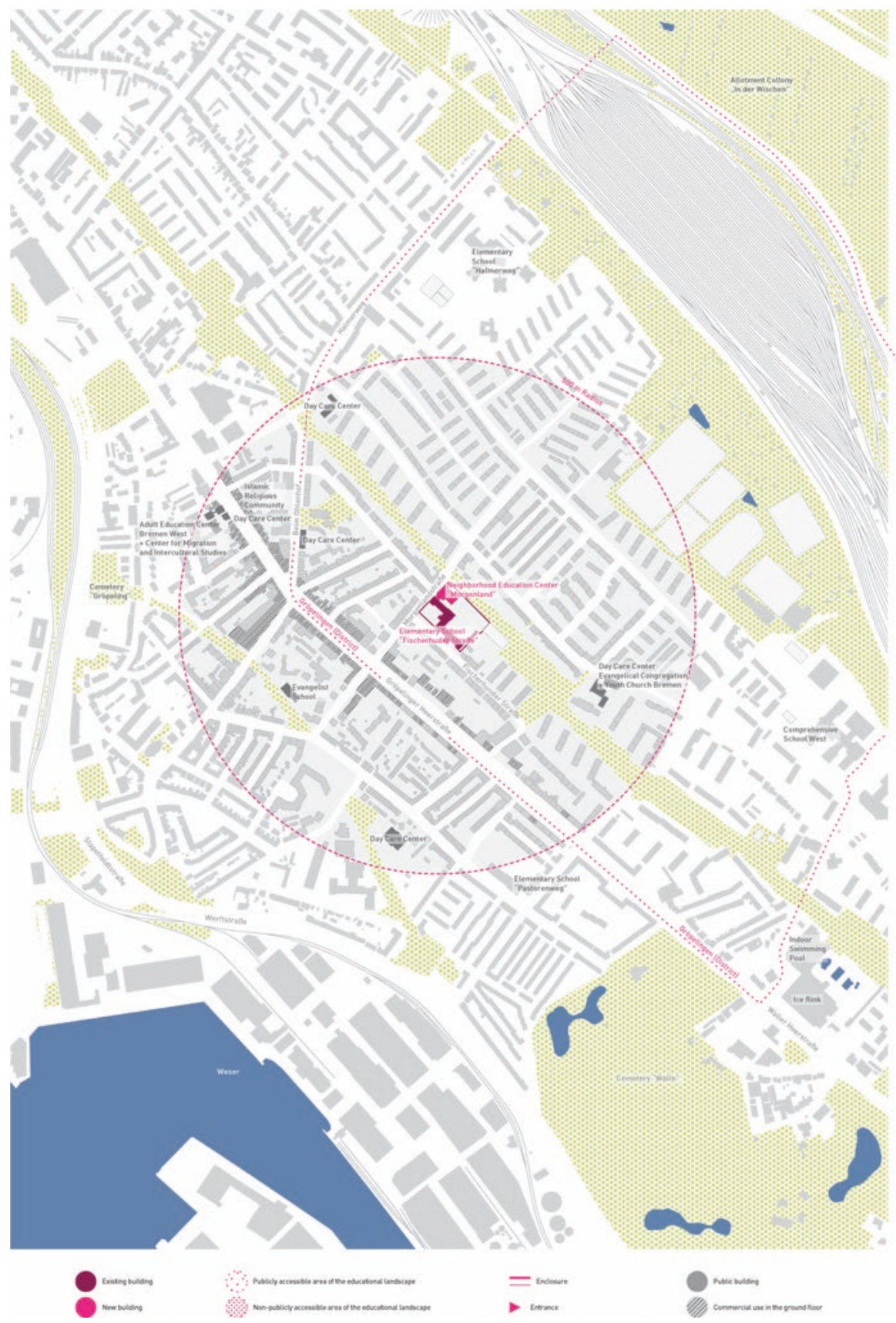

Fig. 3.1 The sociospatial educational landscape QBZ Morgenland Neighborhood Education Center in the "Gröpelingen" neighborhood in the city of Bremen. Reprinted from Million et al. (2017, p. 87). Copyright 2017 by jovis Verlag GmbH. Reprinted with permission. Map data: () OpenStreetMap contributors (License: www.openstreetmap.org/copyright) 


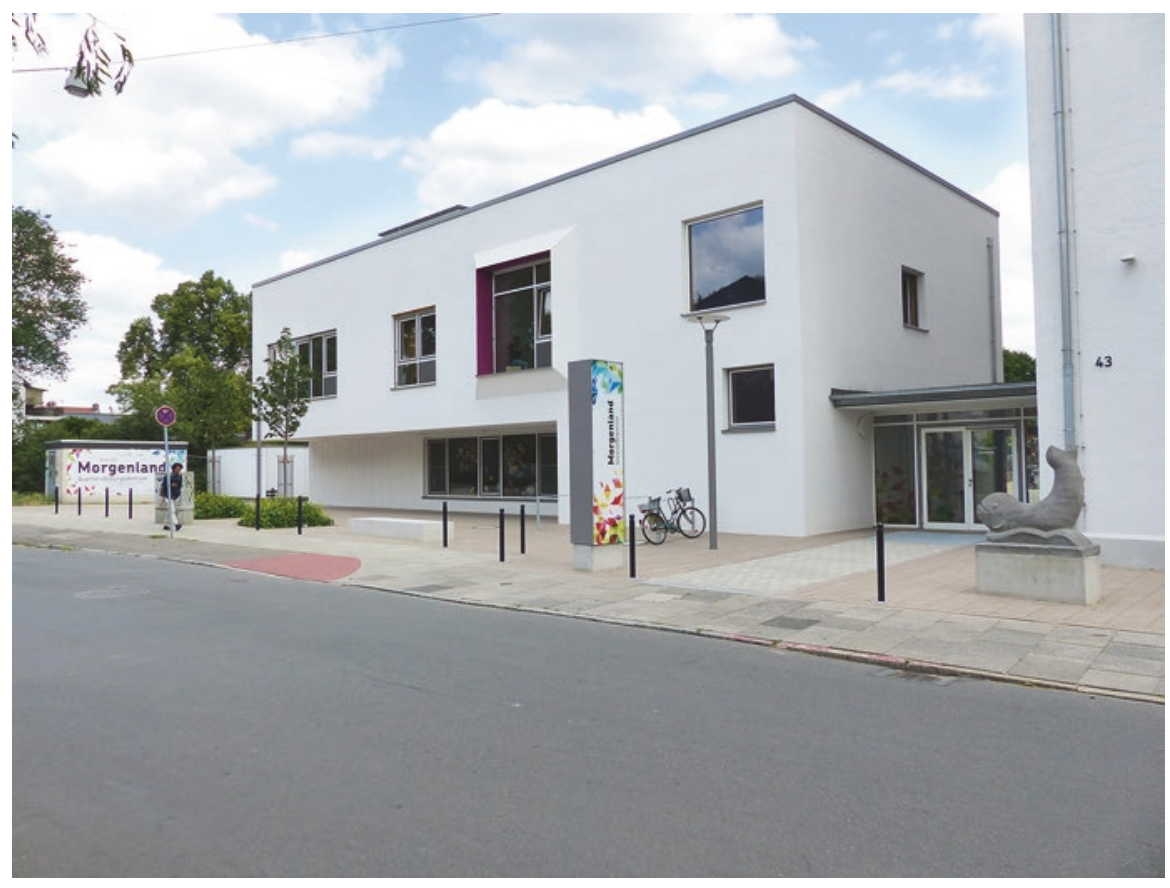

Fig. 3.2 Homebase and office of the QBZ MORGENLAND. Reprinted from Million et al. (2017, p. 86). Copyright 2017 by jovis Verlag $\mathrm{GmbH}$. Reprinted with permission

With the neighborhood education center as a location and the education authorities as partners, the local educational bureau provides five important building blocks for the Gröpelingen education landscape: It coordinates joint activities, points of contact, and transitions in the educational landscape; it provides spaces for general use for educational purposes; it initiates and hosts language and cultural education programs for children up to age 16; it organizes district-related further education opportunities that are used by schools, day-care centers, the library, youth facilities, and others; and it provides space for topic-relevant coordination centers (WiN, educational counseling). The local education bureau is run by the Kultur vor Ort [Culture On-Site] association.

Bremen's neighborhood education centers aim to contribute to equal opportunity and upgrading processes in disadvantaged neighborhoods by supporting organizational cooperation between existing institutions and formal and informal educational settings. With this approach, neighborhood education centers are potential incubators for sociospatial educational landscapes. The spatial relevance of neighborhood education centers and their importance for district development is particularly striking compared to other educational landscapes that we have examined.

The Morgenland Neighborhood Education Center is intended to modify an entire urban district's educational landscape. Its objective is to achieve closer integration between institutions and actors, not to concentrate on a few educational institutions 
in the district. This significantly expands the reference framework, beyond the other examples. We believe that turning an entire neighborhood into an educational landscape with the help of educators and planners, and making it the focus of social urban renewal strategies, is highly ambitious. At the moment, the specific design and implementation seems limited primarily to organizational cooperation. Observers will have to wait and see how the educational landscape's vision is developed in future in relation to public urban space.

\section{Campus Rütli Berlin ${ }^{11}$}

Two day-care centers, a community school, a youth club, a music school, a community college, and other partners have forged an alliance under the title Campus Rütli and have joined forces to improve the living conditions in Berlin's neighbourhood called "Reuterkiez"-for children and adolescents specifically, but also for all residents. Today the institutions are coordinating and working together to design harmonious transitions between institutions, life phases and different activities.

The starting point for Campus Rütli was the problematic situation in the socalled Reuterkiez neighborhood and serious grievances at Rütli High School, made famous by an urgent letter sent by the teaching staff to the Senate Administration for Education in 2006 that later became public. Campus Rütli is located in the Neukölln district of Berlin, and Reuterkiez is the neighborhood around Campus Rütli (see Fig. 3.3). Land development in the Reuterkiez and in the urban district is characterized by five-story, high-density, block-perimeter buildings from the Wilhelmenian period. The playground coverage rate is approximately $45 \%$ of the Berlin standard; green and open spaces account for only $15 \%$ of the standard value (Quartiersbüro Reuterplatz, 2016). Almost half of the inhabitants have a migration background (SenStadt, 2013a, p. 12). The district has an average unemployment rate of $9.5 \%$ (Berlin average: $8.1 \%$ ) and a high proportion of inhabitants receiving social welfare benefits (SenStadt, 2013b, p. 9). As early as 2001, the Reuterplatz neighborhood management area was defined as part of the Social City programme, the funding of which expired in 2016.

Actors brought together various parallel initiatives to create the campus, as it became clear that they comprised similar topics and partially had the same aims. The neighborhood management was instrumental in the conception and realization of Campus Rütli, above all by building on its familiarity with actors in the Reuterkiez and existing networking activities, and by supporting the development of an education network. Two directors were in charge of the development of the Campus Rütli

\footnotetext{
${ }^{11}$ Heinrich (2018) conducted an empirical study is to understand the conceptual framework of the sociospatial educational landscape Campus Rütli from the stakeholders' perspective. Two research questions are answered: What are the reasons for stakeholders of urban planning and urban development to engage in the design of sociospatial educational landscapes? And: What significance do the stakeholders of urban planning and urban development attribute to sociospatial educational landscapes?
} 


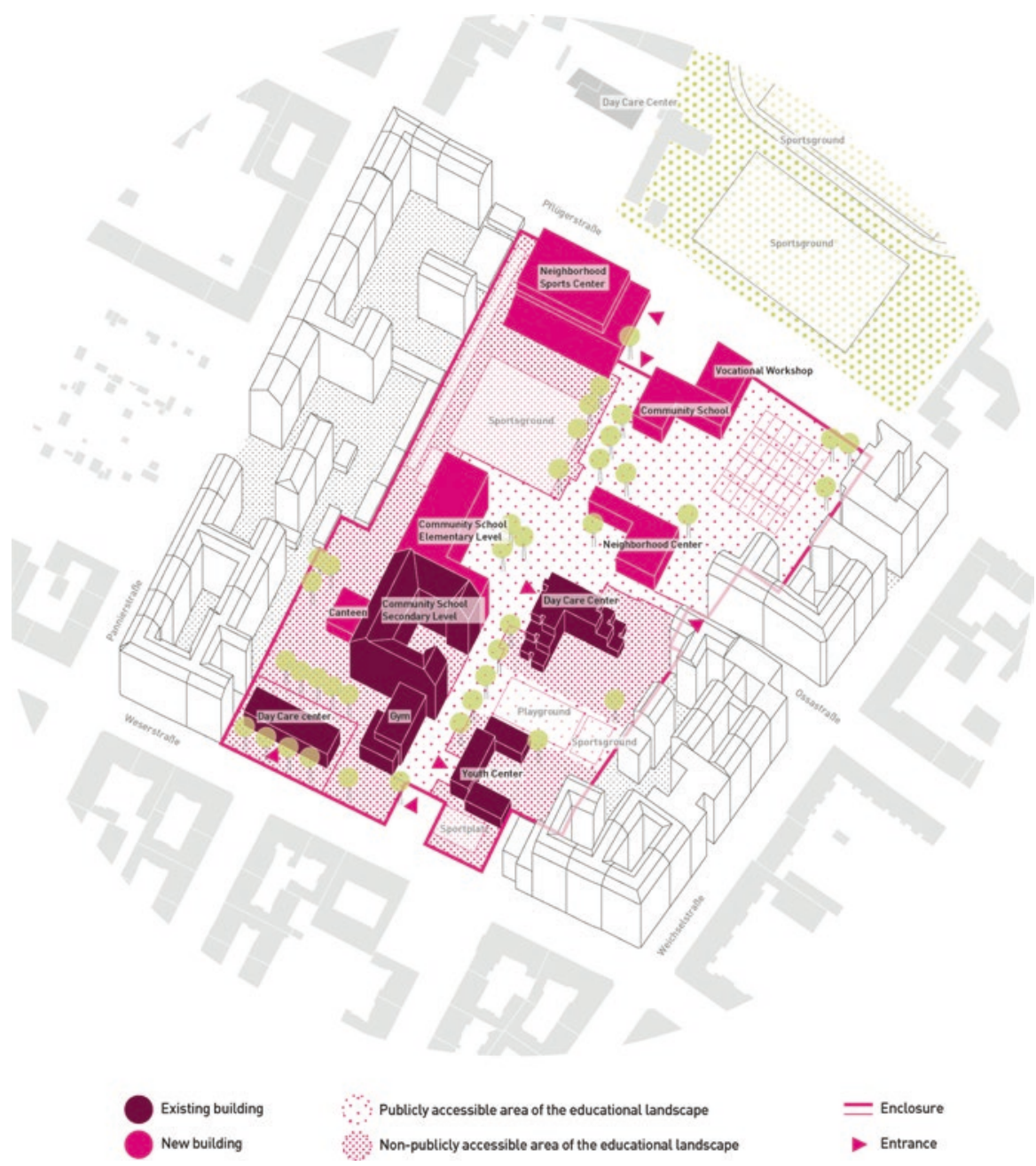

Fig. 3.3 The sociospatial educational landscape Campus Rütli in the "Reuterkiez" neighborhood in Berlin. Reprinted from Million et al. (2017, p. 121). Copyright 2017 by jovis Verlag $\mathrm{GmbH}$. Reprinted with permission. Map data: (C) OpenStreetMap contributors (License: www. openstreetmap.org/copyright)

at the operational level: A retired school principal took over as pedagogical supervisor and a neighborhood manager led the networking and construction management effort. Dual leadership remains a key principle today, despite personnel changes.

In 2011, the signing of the Rahmenkonzeption Campus Rütli [Framework Concept for Campus Rütli] (CR2 2011) formalized the cooperation between actors as a voluntary undertaking. Besides the institutions, signatories included the independent Elterninitiative Reuterkiez [Reuterkiez Parents' Initiative], the neighborhood council, and the Ein Quadratkilometer Bildung [One Square Kilometer of 
Education] program. The Senate Department for Education and the Senate Department for Urban Development, among others, provide administrative support. The involved partners state that the monthly meetings are extremely important for day-to-day cooperation. These are complemented by a bi-annual "political steering committee" for feedback with politicians and representatives of the municipal and state authorities. Other committees include a building committee, which follows the initiated structural measures, and other features include joint training programs (Heinrich, 2018, p. 197).

The first building block of the campus' structural design came with the construction of a new neighborhood sports center, which was completed on campus at the end of 2012. The three-part gymnasium is used for school and club sports. The sports hall and the foyer can also be used for events such as concerts or art exhibitions. Large parts of the campus have been under construction since late 2015. Starting in 2018, the newly built neighborhood center will be home to, among other things, a parent center, the pedagogical workshop, neighborhood coordination, parts of the Youth Welfare Office, a dental service, and the community college. The facility will also provide space for networking activities in the neighborhood. The neighborhood center is intended to serve the goal of lifelong learning. Though the institutional offerings on site and attractive open spaces are meant to encourage neighborhood residents to use the campus, opening the campus to the public is controversial. The neighborhood has seen an influx of artists, creative people, educationminded groups, and high-income households since around 2010, and affordable rental housing has become scarce. A legal protection order for the area was issued in 2016. The school reports initial, tentative changes to the composition of the student body.

The Campus Rütli educational landscape is a good example of how closely the development of an educational site and the development of an entire neighborhood can be intertwined and interrelated. Its conception and realization offer insights even today. The starting point and one of the reasons for creating Campus Rütli was an existing concentration of educational institutions in a small area. Actors saw, and still see, this spatial proximity as a potential factor in the success of organizational cooperation (see Fig. 3.4). Thus, a further concentration of institutions on site should draw additional partners, and transitions in and across young people's school career can be harmoniously organized. Whether the spatial juxtaposition of facilities on a campus also contributes to their harmonious coexistence and cooperation will have to be seen in future day-to-day campus life. Likewise, whether an attractive campus with public spaces can lessen the fear of educational institutions, or whether children and young people will have better educational opportunities, cannot be answered at present. 
3 Educational Inequality and Urban Development: Education as a Field...

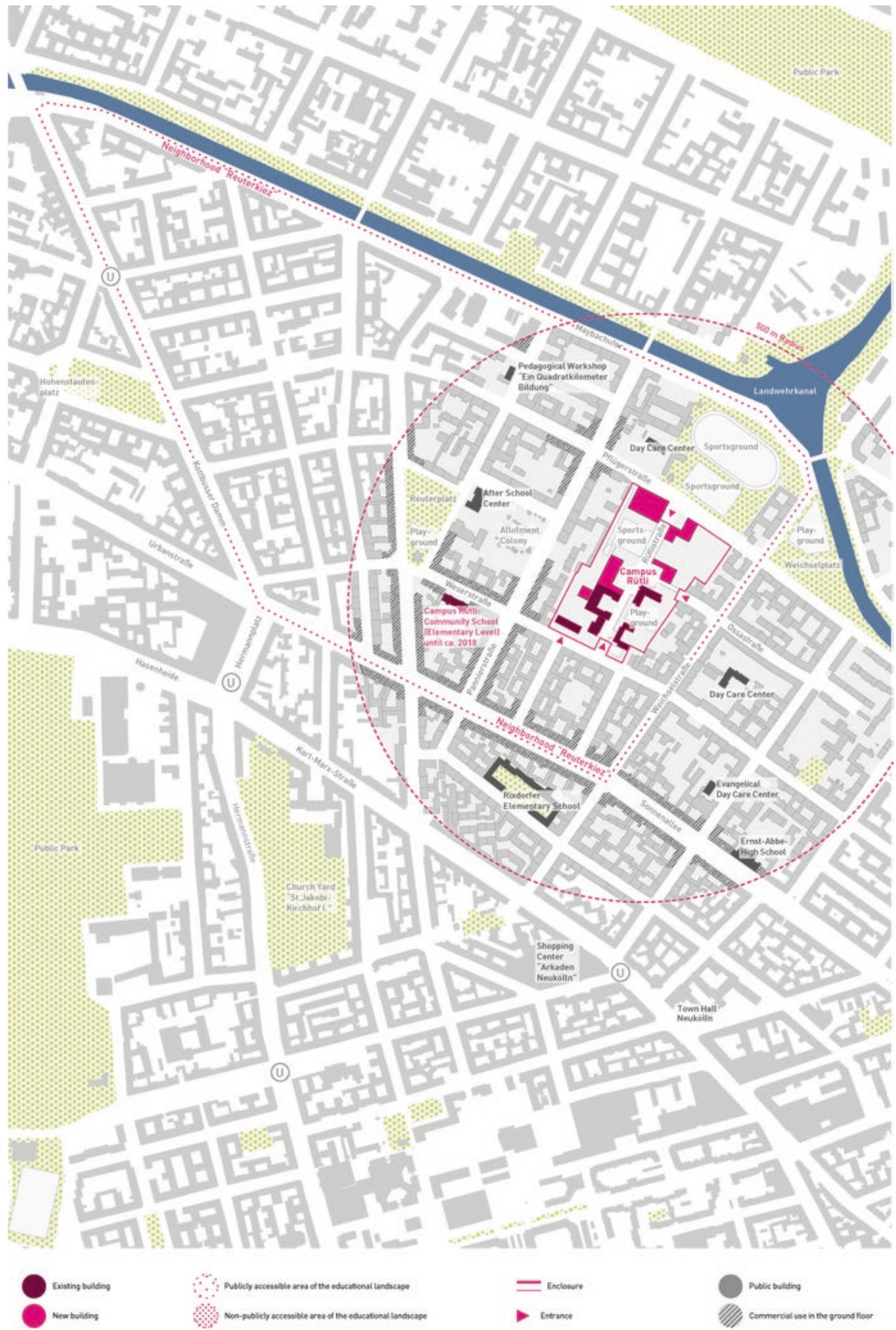

Fig. 3.4 The (possible) future urban design of the Campus Rütli. Reprinted from Million et al. (2017, p. 127). Copyright 2017 by jovis Verlag GmbH. Reprinted with permission. Map data: () OpenStreetMap contributors (License: www.openstreetmap.org/copyright) 


\section{Motives for Creating a Social Environmental Setting to Improve Opportunities for Learning}

The study Gebaute Bildungslandschaften: Verflechtungen zwischen Pädagogik und Stadtplanung [Built Educational Landscapes: Interdependencies between Pedagogy and Urban Planning] (Million et al., 2017) sheds light on the perspective of actors involved in shaping sociospatial educational landscapes. The study's researchers use a detailed analysis of eight cases to explore four main themes of sociospatial educational landscapes: centralization and concentration, networking and interdependence, access and transition, opening and closing (Million et al., 2017, pp. 208-216; see Fig. 3.5). The study of Campus Rütli in Berlin-Neukölln by Heinrich (2018) adds three further motives to the basic characteristics of sociospatial educational landscapes: proximity and connectedness, heterogeneity and individuality, and presentation and representation.

These motives are utilized to answer the question of the deeper meaning that influencing actors (especially educators and urban planners) attribute to their projects. They are the expression of existing and envisaged, idealistic and spatial interdependencies in these stakeholders' thinking and actions-also in the light of targeting inequalities in education.

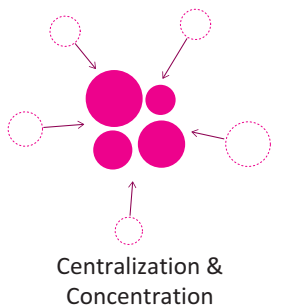

Centralization \&
Concentration

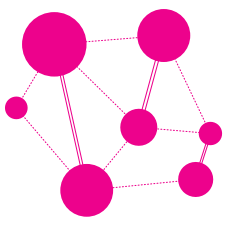

Networking \& Interdependency

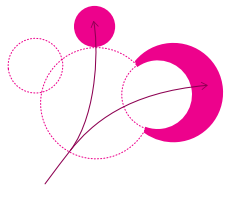

Access \& Transition

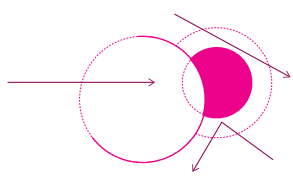

Opening \& Closing

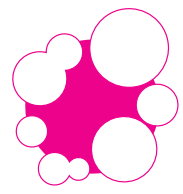

Proximity \& Connectedness

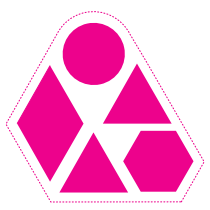

Heterogeneity \& Individuality

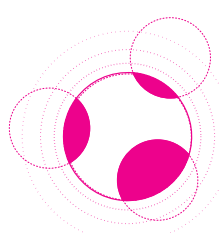

Presentation \& Representation

Fig. 3.5 Motives for the creation of sociospatial educational landscapes. Adapted and translated by permission from Springer Nature Customer Service Centre GmbH \& jovis Verlag GmbH: Springer, Die sozialräumliche Bildungslandschaft Campus Rütli (p. 270), Anna Juliane Heinrich (2018); and jovis, Gebaute Bildungslandschaften (p. 209), Million et al. (2017) 


\section{Centralization and Concentration}

The realization of sociospatial educational landscapes concentrates institutions, times, opportunities, and activities at the educational landscape site. Very often, policymakers take the existing spatial proximity between various educational institutions and settings as the starting point and establish further institutions in the direct vicinity. This usually happens in a central location. This concentration of organizations is meant to intensify exchange and communication between actors and thus help improve organizational cooperation. Concentrating the various institutions attended throughout a student's school career in one place allows children and adolescents to find all the relevant educational institutions at a location already familiar to them. This is meant to alleviate anxieties. The various offered opportunities serve to create points of contact between the educational landscape and all residents in the surrounding area, helping to reduce the fear of entering these educational institutions. Finally, the concentration of facilities should also enable the sharing of infrastructures and contribute to cost reduction.

The concentration of time at the educational landscape location happens in the course of developing full-time school projects. Most sociospatial educational landscapes are centered around an all-day school. With the introduction of all-day educational facilities, curricular and extra-curricular activities, such as homework completion and recreation, are concentrated at the school. As a result, children and adolescents spend much more time at school than before.

The overlapping of various services and activities offered on-site within the educational landscape is meant to create additional added value. Sociospatial educational landscapes should, for example, develop into important meeting places for neighborhood residents and thus become places of communication. This would in turn enhance the attractiveness of the surrounding residential areas. Actors in sociospatial educational landscapes that are implemented in the urban development "campus" framework have particularly high expectations of this added value (Million et al., 2017, pp. 209-211).

\section{Networking and Interdependency}

Sociospatial educational landscapes are a form of organizational cooperation between various actors, settings, institutions, and organizations. Participating partners often organize themselves in the form of a network. Another form of interplay or interdependency in educational landscapes is cross-disciplinary and interdepartmental cooperation in designing sociospatial educational landscapes. The importance of multi-professional teams also increases within individual institutions, for example in neighborhood management and all-day schools.

Another envisioned principle in the conception and realization of sociospatial educational landscapes is spatial networking on different levels of scale. In the case 
of concentrated educational sites, especially campus facilities, this is implemented in two ways: On the one hand, policymakers seek to create "small-scale and closeknit, overlapping of uses in one location" (Million et al., 2017, p. 212; own translation). They also facilitate networking between the educational landscape and the surrounding neighborhood. This can lead, for example, to the creation of visual axes and specially designed entrance situations. In the case of less concentrated and more expansive sociospatial educational landscapes covering a larger area, a further focus would be to create spatial links between different educational settings. However, at the moment it remains largely unclear how this is to be implemented in practice (Million et al., 2017, pp. 212-213).

\section{Access and Transition}

The design of pedagogical and spatial access and transition contexts is an important factor in developing sociospatial educational landscapes. Pedagogically, it is about the smooth success of school-career transitions in childhood and adolescence. Young people should have the opportunity to achieve the highest possible level of formal education and to take advantage of leisure and support opportunities throughout their school career. The transition from school to vocational training or a profession should be facilitated and made easier. In the interest of lifelong learning, adults should be able to access both further education and counseling service, as well as options for re-entry into educational programs.

The structural and creative implementers of sociospatial educational landscapes aim to dismantle not only intangible barriers, but concrete structural impediments as well. Inviting entrances to educational landscapes need to be created and enclosures removed. These measures are based on the assumption that the removal of physical barriers also eases access to an educational landscape's uses and institutions. As a result, the boundaries between public spaces and school spaces may blur, and transitions between areas supervised by educational staff and the less-controlled neighborhood become easier (Million et al., 2017, pp. 213-214; own translation).

\section{Opening and Closing}

Opening is a key objective for all eight of the social-educational landscapes studied. Pedagogues understand opening as a programmatic substantive opening of educational institutions, especially schools. Examples of this include cooperation between various educational organizations and settings, or the opening up of opportunities and infrastructures to new user groups. Structurally, opening means improving an educational landscape's accessibility both to the public and to groups that specifically address the participating institutions. Whereas a structural and creative opening is factored into the design of most educational landscapes, the tension between 
closure and opening manifests itself very differently in implementation. Actors of the less central, larger-scale educational landscapes are building up structurally creative networks and reducing physical barriers in order to ease users' transitions between the various educational settings.

Highly concentrated campus locations discuss opening in two directions. On the one hand, if a campus-centered opening is the objective, institutions understand opening as the "openness of the educational site to the residents of the neighborhood" and invite various target groups to enter the campus and make use of its opportunities and offerings (Million et al., 2017, p. 215). On the other hand, if opening means outward movement from the educational landscape into the urban space and the neighborhood, institutions also use educational settings located outside of the educational landscape. As a result, learners not only spend time on campus but also visit other places in the neighborhood (Million et al., 2017, pp. 214-216).

\section{Proximity and Connectedness}

Proximity and connectedness are core ideas of many sociospatial educational landscapes. The spatial proximity of different educational institutions was one of the starting points for the design of almost all of the examples examined. Spatial proximity favors institutional proximity - this is the conviction of many stakeholders of educational landscapes. For this reason, the spatial realization of an educational landscape often comprises the creation of a campus for all partners or some other form of spatial proximity. The proximity of the actors to each other in terms of contents and concepts as well as common goals are also evaluated as important prerequisites for cooperation. The development of a common concept should strengthen the connectedness among the actors. Accordingly, the actors develop different forms of demonstrating and in some cases formalizing their commitment (e.g., concept papers, contracts).

However, the creation of an educational landscape is not only about the efficiency and effectiveness of the educational institutions, but also about facilitating access to education, harmoniously managing educational transitions and promoting social interaction within the neighborhood. In many places, services directed towards the residents of the neighborhood are created on-site the educational landscape (e.g., sociocultural activities, a public canteen, public open and green spaces). Through meeting and communicating on campus, a place of social interaction in and for the neighborhood is to be created. Social cohesion in the neighborhood is to be strengthened. Consequently, the connectedness among the residents of the neighborhood shall be strengthened (Heinrich, 2018, pp. 270-273). 


\section{Heterogeneity and Individuality}

An educational landscape is a heterogeneous landscape of cooperation. In all the cases analyzed, a great variety of actors and settings (e.g., departments, disciplines, institutions) was the starting point of the conception and realization of the respective sociospatial educational landscape. A further diversification and the cooperation with additional partners (not only from the field of formal education and child-care, but also with companies and cultural institutions in the neighborhood or region) is also part of the conception of all projects.

The heterogeneity of the partners makes it possible to offer a wide range of services and activities in and around educational landscapes. This, in turn, allows to address diverse target groups. The aim of many educational landscapes is to address all residents of the neighborhood with their individual needs and interests-especially in the sense of lifelong learning. Moreover, this heterogeneous range of services is intended to increase the attractiveness of the neighborhood or district as a place to live, thus reducing the out-migration of young people and middle-class households. This is supposed to contribute to a more heterogeneous neighborhood and ultimately to the stabilization of (deprived) neighborhoods.

The motive of individuality is particularly pronounced at the Campus Rütli in Berlin. On account of the newly created institutional structure, young people here can nowadays achieve all school-leaving qualifications. The aim is not for all students to achieve the highest school-leaving certificate, but rather for all students to be able to decide individually on a suitable career path according to their personal wishes, plans, interests and abilities (Heinrich, 2018, pp. 273-277).

\section{Presentation and Representation}

The stakeholders of educational landscapes ascribe great importance to their projects for various forms of presentation and representation. Through their materialization, sociospatial educational landscapes not only become visible, but can also be perceived and experienced with different senses by the users and residents of the neighborhood. The educational landscapes-especially those in the urbanistic figure of the campus - are understood by the actors as a medium of communication. The design of sociospatial educational landscapes is intended to represent the cohesion of the partners and thus to develop an internal identity-forming effect and advertise the educational location to the outside world.

The actors of those educational landscapes in which comprehensive constructional changes have been implemented, pursued the objective to create transparency, visibility and visual relationships through design. Through participatory processes, designs are to be developed that represent the partners and users of sociospatial educational landscapes. By this means, identification with the campus is to be strengthened (Heinrich, 2018, pp. 277-279). 


\section{Critical Discussion and Outlook: Interdisciplinary Perspectives on Education and the Pedagogization of Space}

In this chapter, we have argued that sociospatial educational landscapes are highly significant projects for the social urban development of deprived neighborhoods and beyond. They are innovative approaches to optimizing socioenvironmental settings with regard to learning, based on joint actions by policy and practice in urban planning, design, and education.

We have pointed out that although motivations for creating a social environmental setting to improve opportunities for learning differ, they have a number of key points in common. Heinrich $(2018$, p. 238) categorizes the objectives and motivations formulated by actors in the educational landscape into four thematic areas: (1) networking; (2) value-enhancement and stabilization of a deprived neighborhood; (3) designing school-career transitions; and (4) reinforcing the neighborhood connection on campus, in educational institutions and opportunities. An essential insight from the empirical work of Heinrich (2018), but also that of Million et al. (2017), is that, with these shared objectives and motivations, the separation maintained in municipal practice, and to some degree in scholarship, has already been overcome (even if only in such highly condensed situations as the development of sociospatial educational landscapes in deprived neighborhoods). This raises the interesting question of when and how this interdisciplinary perspective on the part of the actors emerged: whether it already existed, or whether it appeared at the beginning, during, or at the end of the process of developing a sociospatial educational landscape project - although an educational landscape is presumably never finished, but in a constant process of "developing." With regard to educational landscapes, Duveneck (2016, p. 88) concludes critically that willingness to engage in educational networking is a reaction to policy pressure to produce human capital, which is passed on to social subjects and results in improvement of young peoples' opportunities in life. Because communities engaged in intermunicipal competition are under pressure to make their local resources competitive, they develop structures to make them comply with public policy. With this approach, Duveneck's (2016) study is one of the few critical contributions to the debate on educational landscapes where hardly any critical views have been heard (Mattern \& Lindner, 2015, p. 83).

There are several reasons to believe that urban planning will also address educational issues in the future, and that actors will develop more sociospatial educational landscapes to solve urgent social problems. These issues include the importance of origin and background for educational success, social segregation in cities, and the overdue renovation of many school buildings in Germany. There will be a need for action in these areas in the future.

Finally, we have shown that sociospatial educational landscapes are a highly coherent conceptual framework for diverse groups of actors. Different aims and objectives can be pursued, and goal conflicts tend to be few (Heinrich, 2018). At the same time, it is as yet impossible to say whether the quality of learning in 
sociospatial educational landscapes has improved. The implemented examples are still young and need to prove themselves as educational settings in practice, and as a benefit for the neighborhood. There are voices that criticize the concentration of learning activities in socioeducational landscapes, the scholarization of the leisure time of children and adolescents in and through sociospatial educational landscapes (Million et al., 2017, p. 228), and the unbounding (Entgrenzung) of pedagogy in these sociospatial contexts (Castillo Ulloa, Million, \& Schwerer, 2022). It is a pedagogy that underpins space. It refers to a spatialization which advances arrangements subtle or directly, in order to establish specific perceptions and uses of space. The pedagogical then is not limited to formal processes and arenas of school. It includes the wider spatial context of neighborhoods and even homes as designed and planned setting for learning and co-education-with open outcome on growing up in such an optimized environment.

\section{References}

Albers, G. (1983). Stadtplanung als komplexer Steuerungsvorgang [Urban planning as a complex control process]. In G. Albers (Ed.), Grundriss der Stadtplanung (pp. 342-353). Hanover: Vincentz.

Albers, G. (2005a). Geschichte der örtlichen Raumplanung [History of local spatial planning]. In P. Treuner (Ed.), Handwörterbuch der Raumordnung (pp. 381-383). Hanover: ARL.

Albers, G. (2005b). Stadtentwicklungsplanung [Urban Development Planning]. In P. Treuner (Ed.), Handwörterbuch der Raumordnung (pp. 1067-1071). Hanover: ARL.

Altrock, U. (2014). Das Ende der Angebotsplanung? Instrumente der Planung im Wandel [The end of tender planning? Instruments of planning in change]. In P. Küpper, M. Levin-Keitel, F. Maus, P. Müller, S. Reimann, M. Sondermann, K. Stock, \& T. Wiegand (Eds.), Raumentwicklung 3.0: Gemeinsam die Zukunft der räumlichen Planung gestalten (pp. 15-32). Arbeitsberichte der ARL: Vol. 8. Hanover: ARL.

Baumheier, U., \& Warsewa, G. (2009). Vernetzte Bildungslandschaften: Internationale Erfahrungen und Stand der deutschen Entwicklung [Networking educational landscapes: International experiences and the state of German development]. In P. Bleckmann \& A. Durdel (Eds.), Lokale Bildungslandschaften: Perspektiven für Ganztagsschulen und Kommunen (pp. 19-36). Wiesbaden: VS Verlag für Sozialwissenschaften.

Berse, C. (2009). Mehrdimensionale Bildung im Kontext kommunaler Bildungslandschaften: Bestandsaufnahme und Perspektiven [Multidimensional education in the context of municipal educational landscapes: Stocktaking and perspectives]. Opladen: Budrich UniPress.

Biernath, A., Heußen, E., Ahnfeldt, B., Kalben, T., Luchterhandt, D., Burgdorff, F., Gräbener, M., \& Herrmann, M. (2009). Die Rolle der Bildung in der nationalen Stadtentwicklungspolitik: Drei Thesen [The role of education in national urban development policy: Three theses]. Retrieved from https://www.nationale-stadtentwicklungspolitik.de/NSP/SharedDocs/Downloads/DE/_ Anlagen/bildung_thesen.html

Bischoff, A., Selle, K., \& Sinning, H. (2007). Informieren, Beteiligen, Kooperieren: Kommunikation in Planungsprozessen: Eine Übersicht zu Formen, Verfahren und Methoden [Inform, involve, cooperate: Communication in planning processes: An overview of forms, procedures and methods]. Dortmund: Dortmunder Vertrieb für Bau- und Planungliteratur.

Bleckmann, P., \& Durdel, A. (2009). Einführung: Lokale Bildungslandschaften—die zweifache Öffnung [Introduction: Local educational landscapes - the dual opening]. In P. Bleckmann \& A. Durdel (Eds.), Lokale Bildungslandschaften: Perspektiven für Ganztagsschulen und Kommunen (pp. 11-16). Wiesbaden: VS Verlag für Sozialwissenschaften. 
Bollweg, P., \& Otto, H. (2011). Bildungslandschaft: Zur subjektorientierten Nutzung und topologischen Ausgestaltung [Educational landscape: On subject-oriented use and topological design]. In P. Bollweg \& H. Otto (Eds.), Räume flexibler Bildung: Bildungslandschaft in der Diskussion (pp. 13-35). Wiesbaden: VS Verlag für Sozialwissenschaften.

Böhme, C., \& Franke, T. (2015). Schule und Bildung im Programm „Soziale Stadt“ [School and education in the "Socially Integrative City" programme]. In T. Coelen, A. J. Heinrich, \& A. Million (Eds.), Stadtbaustein Bildung (pp. 35-42). Wiesbaden: Springer VS.

Bundesinstitut für Bau-, Stadt- und Raumforschung im Bundesamt für Bauwesen und Raumordnung. (BBSR). (2015). Vorbereitung einer ressortübergreifenden Strategie „Soziale Stadt" [Preparation of an interdepartmental "Socially Integrative City" strategy]. Retrieved from https://www.bbsr.bund.de/BBSR/DE/FP/Weitere/StrategieSozialeStadt/01-start.html?nn= 437320

Bundesinstitut für Bau-, Stadt- und Raumforschung im Bundesamt für Bauwesen und Raumordnung. (BBSR). (2017a). Stadt: Pilot Spezial: Zehn Jahre Pilotprojekte der Nationalen Stadtentwicklungspolitik [City: Pilot Special: Ten years of pilot projects in national urban development policy]. Bonn: Bundesinstitut für Bau-, Stadt- und Raumforschung im Bundesamt für Bauwesen und Raumordnung.

Bundesinstitut für Bau-, Stadt- und Raumforschung im Bundesamt für Bauwesen und Raumordnung. (BBSR). (2017b). Kreativ aus der Krise: Impulse für städtische Transformationen [Creatively out of the crisis: Impulses for urban transformations]. Bonn: Bundesinstitut für Bau-, Stadtund Raumforschung im Bundesamt für Bauwesen und Raumordnung.

Bundesinstitut für Bau-, Stadt- und Raumforschung im Bundesamt für Bauwesen und Raumordnung. (BBSR). (2017c). Städtebauförderung: Soziale Stadt [Urban development funding: Socially Integrative City]. Retrieved from http://www.staedtebaufoerderung.info/ StBauF/DE/Programm/SozialeStadt/soziale_stadt_node.html

Bundesministerium für Umwelt, Naturschutz, Bau und Reaktorsicherheit. (BMUB). (2007). LEIPZIG CHARTER on Sustainable European Cities. Retrieved from https:// www.bmu.de/fileadmin/Daten_BMU/Download_PDF/Nationale_Stadtentwicklung/ leipzig_charta_en_bf.pdf

Bundesministerium für Umwelt, Naturschutz, Bau und Reaktorsicherheit. (BMUB). (2014). Statusbericht Soziale Stadt 2014: Berichtszeitraum 2009-2014 [Socially Integrative City 2014 status report: reporting period 2009-2014]. Retrieved from https://www. staedtebaufoerderung.info/StBauF/SharedDocs/Publikationen/StBauF/SozialeStadt/ StatusberichtProgrammSozialeStadt2014.pdf?_blob=publicationFile\&v=9

Bundestransferstelle Soziale Stadt. (2006). Dritte bundesweite Befragung in den Programmgebieten „Soziale Stadt": Zentrale Ergebnisse und Empfehlungen [Third nationwide survey in the "Socially Integrative City" program areas: Key findings and recommendations]. Arbeitspapiere zum Programm Soziale Stadt: Vol. 12. Berlin: Deutsches Institut für Urbanistik.

Burgdorff, F., \& Herrmann-Lobreyer, M. (2010). Bildung im Rahmen der Nationalen Stadtentwicklungspolitik: Ausgangssituation, erste Projekte und ein gemeinsames Thesenpapier [Education within the framework of national urban development policy: initial situation, first projects and a joint thesis paper]. Informationen zur Raumentwicklung, 2/3, 143-154.

Castillo Ulloa, I., Million, A., \& Schwerer, J. (2022). "I spy with my little eye": Children's actual use and experts' intended design of public space. In A. Million, C. Haid, I. Castillo Ulloa, $\&$ N. Baur (Eds.), Spatial transformations: Kaleidoscopic perspectives on the refiguration of spaces. London: Routledge.

Campus Rütli. (Ed.). (2011). Rahmenkonzeption Campus Rütli-CR2: Über die Zusammenarbeit der Akteure auf dem Campus Rütli [Framework Concept for Campus Rütli-CR2: About the cooperation of the actors on the Campus Rütli]. Retrieved from http://campusruetli.de/cr2uploads/2014.10/CR2Rahmenkonzeption\%2819.03.2011\%29.pdf

du Bois-Reymond, M. (2011). Bildungslandschaften in einem offenen Europa: Das Beispiel Niederlande [Educational landscapes in an open Europe: The example of the Netherlands]. In P. Bollweg \& H. Otto (Eds.), Räume flexibler Bildung: Bildungslandschaft in der Diskussion (pp. 519-532). Wiesbaden: VS Verlag für Sozialwissenschaften. 
Duveneck, A. (2016). Bildungslandschaften verstehen: Zum Einfluss von Wettbewerbsbedingungen auf die Praxis [Understanding educational landscapes: The influence of competitive conditions on practice]. Weinheim: Beltz Juventa.

Fischer, F., \& Forester, J. (1993). The argumentative turn in policy analysis and planning. Durham, UK: Duke University Press.

Forester, J. (1999). The deliberative practitioner: Encouraging participatory planning processes. Cambridge, MA: MIT Press.

Friedrichs, J. (2005). Integrierte Stadtentwicklung [Integrated urban development]. In P. Treuner (Ed.), Handwörterbuch der Raumordnung (pp. 1063-1068). Hanover: Akademie für Raumforschung und Landesplanung.

Grabow, B., \& Uttke, A. (2010). Leitbilder nachhaltiger Stadtentwicklung: Von der lokalen Agenda zur Nachhaltigkeit als strategischem Rahmen [Guiding principles of sustainable urban development: From the local agenda to sustainability as a strategic framework]. PLANERIN, 6, 22-25.

Güntner, S. (2007). Soziale Stadtpolitik: Institutionen, Netzwerke und Diskurse in der Politikgestaltung [Social urban policy: Institutions, networks and discourses in policy-making]. Bielefeld: transcript.

Häußermann, H. (2002). Die Krise der „Sozialen Stadt" [The crisis of the "Socially integrative city"]. Aus Politik und Zeitgeschichte, B 10-11. Retrieved from https://www.bpb.de/ apuz/25698/die-krise-der-sozialen-stadt? $\mathrm{p}=$ all

Häußermann, H., Läpple, D., Siebel, W. (2007). Stadtpolitik [Urban policy]. Frankfurt: Suhrkamp.

Häußermann, H., \& Siebel, W. (2004). Stadtsoziologie: Eine Einführung [Urban sociology: An introduction]. Frankfurt, New York: Campus.

Healey, P. (1996). The communicative turn in planning theory and its implications for spatial strategy formations. Environment and Planning B, 23, 217-234. https://doi.org/10.1068/b230217

Healey, P. (1997). Collaborative planning: Shaping places in fragmented societies. London: Macmillan.

Heinrich, A. J. (2018). Die sozialräumliche Bildungslandschaft Campus Rütli in Berlin-Neukölln: Begründungen und Bedeutungen aus der Perspektive gestaltender Akteure [The sociospatial educational landscape Campus Rütli in Berlin-Neukölln: Reasons and significance from the stakeholders' perspective]. Wiesbaden: Springer VS.

IBA Hamburg. (2009). Metropole 3: Bilden [Metropolis 3: Education]. Berlin: Jovis.

IBA Hamburg. (2010). IBA Meets IBA: Zur Zukunft Internationaler Bauausstellungen [IBA meets IBA: The future of International Building Exhibitions]. Berlin: Jovis.

Kultur Vor Ort e. V. (2017). QBZ Morgenland: Das neue Quartiers-Bildungszentrum [QZB Morgenland: The new neighborhood education center]. Retrieved from http://www. gröpelingen-bildet.de/index.php?we_objectID=17

Libbe, J., Köhler, H., \& Beckmann, K. (2010). Infrastruktur und Stadtentwicklung: Technische und soziale Infrastrukturen: Herausforderungen und Handlungsoptionen für Infrastrukturund Stadtplanung [Infrastructure and urban development: Technical and social infrastructures: Challenges and options for action for infrastructure and urban planning]. Berlin: Deutsches Institut für Urbanistik.

Mack, W. (2008). Bildungslandschaften [Educational landscapes]. In T. Coelen \& H. Otto (Eds.), Grundbegriffe Ganztagsbildung: Das Handbuch (pp. 741-749). Wiesbaden: VS Verlag für Sozialwissenschaften. https://doi.org/10.1007/978-3-531-91161-8_74

Mattern, P., \& Lindner, M. (2015). Warum Bildungslandschaften? Einige Überlegungen zu Form und Funktion einer eigenartigen Figur [Why educational landscapes? Some thoughts about form and function of a peculiar figure]. Widersprüche: Zeitschrift für sozialistische Politik im Bildungs-, Gesundheits- und Sozialbereich, 35, 81-95.

Matthiesen, U., \& Mahnken, G. (2009). Das Wissen der Städte: Neue stadtregionale Entwicklungsdynamiken im Kontext von Wissen, Milieus und Governance [The knowledge of cities: New urban regional development dynamics in the context of knowledge, milieus and governance]. Wiesbaden: VS Verlag für Sozialwissenschaften.

Mecklenbrauck, I. (2015). Universitätsstandorte der 1960er und 1970er Jahre: Eine empirische Analyse von Rahmenbedingungen und Herausforderungen in der Wissensgesellschaft [University locations of the 1960s and 1970s: An empirical analysis of framework condi- 
tions and challenges in the knowledge society] (Doctoral dissertation). Dortmund, Germany: Technische Universität Dortmund.

Million, A., Coelen, T., Heinrich, A. J., Loth, C., \& Somborski, I. (2017). Gebaute Bildungslandschaften: Verflechtungen zwischen Pädagogik und Stadtplanung [Built educational landscapes: Interlinkages between pedagogy and urban planning]. Berlin: Jovis.

Million, A., Heinrich, A. J., \& Coelen, T. (2015). Educational landscapes and urban development: Contextual and spatial interfaces and linkages. Planning Practice \& Research, 5, 587-601. https://doi.org/10.1080/02697459.2015.1023069

Ministerium für Landesentwicklung und Verkehr des Landes Sachsen-Anhalt. (MLVLSA). (2010). Internationale Bauausstellung Sachsen-Anhalt 2010: Weniger ist Zukunft: 19 Städte-19 Themen [International Building Exhibition Saxony-Anhalt 2010: Less is future: 19 cities-19 themes]. Berlin: Jovis.

Quartiersbüro Reuterplatz. (2016). Quartiersmanagement Reuterplatz: Unser Quartier [Neighborhood management „Reuterplatz“: Our neighborhood]. Retrieved from http://www. reuter-quartier.de/unser-quartier.154.0.html

Rittel, H. W. J., \& Webber, M. M. (1973). Dilemmas in a general theory of planning. Policy Sciences, 4, 155-169. https://doi.org/10.1007/BF01405730

Selle, K. (2012). Stadtentwicklung aus der „Governance-Perspektive“: Eine veränderte Sicht auf den Beitrag öffentlicher Akteure zur räumlichen Entwicklung: Früher und heute [Urban development from the "governance perspective": A changed view on the contribution of public actors to spatial development: Past and present]. In U. Altrock \& G. Bertram (Eds.), Wer entwickelt die Stadt? Geschichte und Gegenwart lokaler Governance: Akteure-Strategien-Strukturen (pp. 27-48). Bielefeld: transcript.

Senatorin für Bildung und Wissenschaft. (2014). Lokales Bildungsbüro Gröpelingen: Erfahrungen, Konzepte, Projekte [Local education bureau in Groepelingen: Experiences, concepts, projects]. Retrieved from http://www.gröpelingen-bildet.de/Downloads/PDF/Lokales_Bildungsbuero_ Groepelingen.pdf

Senatsverwaltung für Stadtentwicklung und Umwelt. (SenStadt). (2013a). Monitoring Soziale Stadtentwicklung 2013: 4.1. Kontextindikatoren-Anteilswerte auf Ebene der Planungsräume [Monitoring of the social urban development of Berlin 2013: Contextual indicatorsProportional values at planning area level]. Retrieved from http://www.stadtentwicklung.berlin.de/planen/basisdatenstadtentwicklung/monitoring/download/2013/tab/4.1.KontextIndAnte ilePLRMSS2013.pdf

Senatsverwaltung für Stadtentwicklung und Umwelt. (SenStadt). (2013b). Monitoring Soziale Stadtentwicklung 2013: 2.1. Index-Indikatoren nach Status und Dynamik- Anteilswerte auf Ebene der Planungsräume [Monitoring of the social urban development of Berlin 2013: Index indicators by status and dynamism - Proportional values at planning area level]. Retrieved from http://www.stadtentwicklung.berlin.de/planen/basisdatenstadtentwicklung/monitoring/ download/2013/tab/2.1.IndexIndAnteilePLRMSS2013.pdf

Sinning, H. (2007). Stadtplanung—Stadtentwicklung—Stadtmanagement: Herausforderungen für eine Nationale Stadtentwicklungspolitik [Urban planning — urban development—urban management: Challenges for a national urban development policy]. vhw Forum Wohneigentum, 6, 303-308.

Sinz, M. (2005). Raumordnung/Raumordnungspolitik [Regional planning/spatial development policy]. In E.-H. Ritter (Ed.), Handwörterbuch der Raumordnung (pp. 863-871). Hanover: ARL.

Spehl, H. (2005). Nachhaltige Raumentwicklung [Sustainable spatial development]. In E.-H. Ritter (Ed.), Handwörterbuch der Raumordnung (pp. 679-684). Hanover: ARL.

Stadt Heidelberg, Dezernat für Bauen und Verkehr, Stadtplanungsamt. (2012). Wissen schafft Stadt: Internationale Bauausstellung Heidelberg. Dokumentation Auftaktveranstaltung am 04. und 05. Oktober 2012 [Knowledge based urbanism: International Building Exhibition Heidelberg. Documentation of the launching event on 4 and 5 October 2012]. Retrieved from http://www.iba.heidelberg.de/files/61_pdf_iba_wissenschafftstadt_dokumentation_auftaktveranstaltung.pdf

Steffen, G., Burgdorff, F., von Kalben, T., Luchterhandt, D., Senger, D., \& Heußen, E. (2009). Bildung in der Nationalen Stadtentwicklungspolitik: Die zentralen Forschungsleitfragen und 
die Antworten aus den Projekten [Education in national urban development policy: The central research questions and the answers from the projects]. Retrieved from https://www.nationalestadtentwicklungspolitik.de/NSP/SharedDocs/Downloads/DE/_Anlagen/bildung_leitfragen. pdf?_blob=publicationFile\&v $=1$

Stegen, R. (2006). Die soziale Stadt: Quartiersentwicklung zwischen Städtebauförderung, integrierter Stadtpolitik und Bewohnerinteressen [The social city: Quarter development between promotion of town planning, integrated city policy and residents' interests] (dissertation). Schriften des Arbeitskreises Stadtzukünfte der Deutschen Gesellschaft für Geographie: Vol. 3. Berlin: Lit.

Zimmermann, K. (2010). Der veränderte Stellenwert von Wissen in der Planung [The changing importance of knowledge in planning]. Raumforschung und Raumordnung, 68, 115-125. https://doi.org/10.1007/s13147-009-0010-1

Open Access This chapter is licensed under the terms of the Creative Commons Attribution 4.0 International License (http://creativecommons.org/licenses/by/4.0/), which permits use, sharing, adaptation, distribution and reproduction in any medium or format, as long as you give appropriate credit to the original author(s) and the source, provide a link to the Creative Commons license and indicate if changes were made.

The images or other third party material in this chapter are included in the chapter's Creative Commons license, unless indicated otherwise in a credit line to the material. If material is not included in the chapter's Creative Commons license and your intended use is not permitted by statutory regulation or exceeds the permitted use, you will need to obtain permission directly from the copyright holder. 